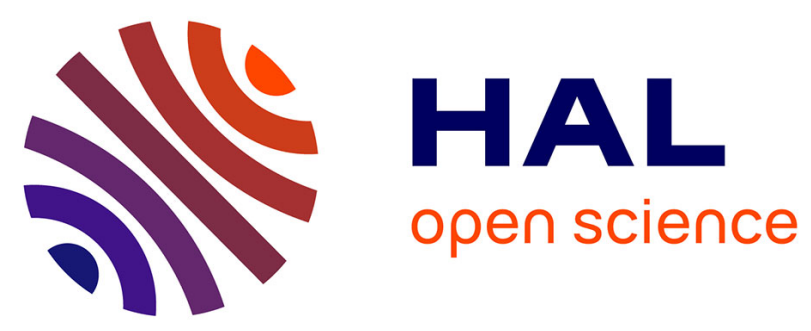

\title{
Chiral Transmission to Cationic Polycobaltocenes over Multiple Length Scales Using Anionic Surfactants
} Rebecca A Musgrave, Paul Choi, Robert L Harniman, Robert M Richardson, Chengshuo Shen, George R Whittell, Jeanne Crassous, Huibin Qiu, Ian Manners

\section{To cite this version:}

Rebecca A Musgrave, Paul Choi, Robert L Harniman, Robert M Richardson, Chengshuo Shen, et al.. Chiral Transmission to Cationic Polycobaltocenes over Multiple Length Scales Using Anionic Surfactants. Journal of the American Chemical Society, 2018, 140 (23), pp.7222-7231. 10.1021/jacs.8b03112 . hal-01807878

HAL Id: hal-01807878

https://hal-univ-rennes1.archives-ouvertes.fr/hal-01807878

Submitted on 3 Sep 2018

HAL is a multi-disciplinary open access archive for the deposit and dissemination of scientific research documents, whether they are published or not. The documents may come from teaching and research institutions in France or abroad, or from public or private research centers.
L'archive ouverte pluridisciplinaire HAL, est destinée au dépôt et à la diffusion de documents scientifiques de niveau recherche, publiés ou non, émanant des établissements d'enseignement et de recherche français ou étrangers, des laboratoires publics ou privés. 


\title{
Chiral Transmission to Cationic Polycobaltocenes over Multiple Length Scales using Anionic Surfactants
}

\author{
Rebecca A. Musgrave, ${ }^{1}$ Paul Choi, ${ }^{1}$ Robert L. Harniman, ${ }^{1}$ Robert M. Richardson, ${ }^{2}$ Chengshuo Shen, ${ }^{3}$ \\ George R. Whittell, ${ }^{1}$ Jeanne Crassous, ${ }^{4}$ Huibin Qiu ${ }^{3, *}$ and Ian Manners ${ }^{1, *}$.
}

${ }^{1}$ School of Chemistry and 2 School of Physics, University of Bristol, Bristol, BS8 1TS, United Kingdom.

3School of Chemistry and Chemical Engineering, Shanghai Jiao Tong University, Shanghai 200240, China.

${ }^{4}$ Institut des Sciences Chimiques de Rennes UMR 6226, CNRS Université de Rennes 1, Campus de Beaulieu, 35042

Rennes Cedex, France.

\begin{abstract}
Chiral polymers are ubiquitous in nature, and the self-assembly of chiral materials is a field of widespread interest. In this paper we describe the formation of chiral metallopolymers based on poly(cobaltoceniumethylene) ([PCE $]^{\mathrm{n}+}$ ), which have been prepared through oxidation of poly(cobaltocenylethylene) (PCE) in the presence of enantiopure $N$-acylamino acid-derived anionic surfactants, such as $N$-palmitoyl-L-alanine $\left(\mathrm{C}_{16}\right.$-L-Ala) and $N$-palmitoyl-D-alanine ( $\mathrm{C}_{16}$-D-Ala). It is postulated that the resulting metallopolymer complexes [PCE] $\left[\mathrm{C}_{16}-\mathrm{L} / \mathrm{D}-\mathrm{Ala}\right]_{\mathrm{n}}$ contain close ionic contacts, and exhibit chirality through the axially chiral ethylenic $\mathrm{CH}_{2}-\mathrm{CH}_{2}$ bridges, leading to interaction of the chromophoric [CoCp $]^{+}$units through chiral space. The steric influence of the long palmitoyl $\left(\mathrm{C}_{16}\right)$ surfactant tail is key for the transcription of chirality to the polymer, and results in a brush-like amphiphilic macromolecular structure that also affords solubility in polar organic solvents (e.g. EtOH, THF). Upon dialysis of these solutions into water, the hydrophobic palmitoyl surfactant substituents aggregate and the complex assembles into superhelical ribbons with identifiable 'handedness', indicating the transcription of chirality from the molecular surfactant to the micron length scale, via the macromolecular complex.
\end{abstract}

\section{INTRODUCTION}

High molar mass metallopolymers are of growing interest as a result of the combination of their functionality, arising from the presence of metal centers, and the facile processing characteristics of macromolecular materials. ${ }^{1-8}$ Examples of metallopolymers that display redox activity have attracted considerable attention and have recently found application in electrocatalysis $^{9-11}$ and sensing, ${ }^{12-14}$ and as responsive surfaces $^{15-19}$ and capsules. ${ }^{20-21}$ Their utility as precursors to catalytic and magnetic nanoparticles has also been wellinvestigated.22-29 However, although chiral organic polymers are well-developed and are of considerable current interest as functional materials with potential applications in chiral recognition, asymmetric catalysis and enantioselective discrimination, ${ }^{30-31}$ analogous metallopolymers, which may display additional advantageous properties, are virtually unexplored. Rare examples of metal-containing chiral macromolecular materials include helical cobaltocenium oligomers (e.g. 1, Fig 1, with 2-6 repeat units), ${ }^{32-33}$ low molecular weight nickel-containing helical ladder polymers based on salophen units (e.g. 2, Fig 1, number average degree of polymerization $\left.\mathrm{DP}_{\mathrm{n}} \leq 10\right),{ }^{34-35}$ and coordination polymers incorporating chiral ligands (e.g. 3, Fig. 1). ${ }^{36-37}$

Transfer of chirality from molecules to nano- and macroscopic structures can be achieved by self-assembly, where molecular chirality is amplified on a larger length scale by cooperative non-covalent interactions, such as hydrogen bonding, $\pi-\pi$ aromatic stacking, ${ }^{38-40}$ ion-dipolar interactions, and electrostatic interactions.40-41 of relevance to this work are a series of organic achiral polymers, which have been shown to exhibit optical activity upon complexation with chiral guests. ${ }^{30}$ These 'dynamic helical polymers' rely on non-covalent interactions with the chiral guest in order to induce helicity within the polymer structure. ${ }^{30}$ Another fascinating recent report on metal-containing chiral assemblies involves the synthesis of organogelator nanoribbons and their templating of Au-nanocrystals to form double-helical Au nanowires. ${ }^{42}$ 


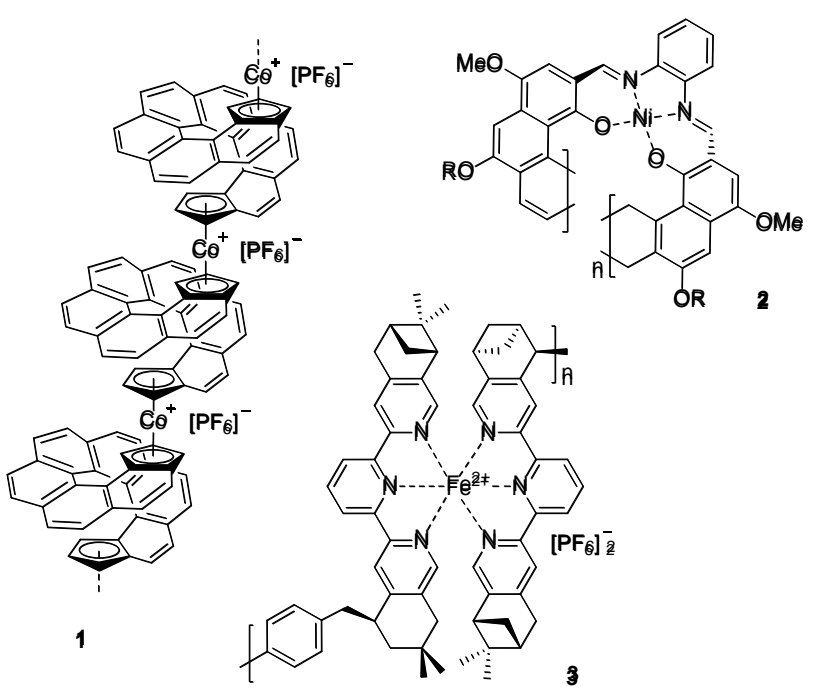

Figure 1. Metal-containing chiral oligomers and coordination polymers 1-3.

Recently, our group reported the thermal ring-opening polymerization (ROP) of the strained dicarba[2]cobaltocenophane monomer (4) to yield high molecular weight neutral poly(cobaltocenylethylene) (PCE) with degree of polymerization $n$, which features neutral cobaltocene units in the main chain of the polymer (Fig. 2). Upon one-electron oxidation of the cobaltocene units, poly(cobaltoceniumethylene), $[\mathrm{PCE}][\mathrm{X}]_{\mathrm{n}}\left(\mathrm{X}=\mathrm{Cl}^{-}\right.$, $\mathrm{NO}_{3}{ }^{-}$, -OTf (-OTf = trifluoromethanesulfonate)), is formed (Fig. 2). ${ }^{43-44}$ Unlike related ferrocene-containing polymer analogues such as polyferrocenylsilane (PFS) (Fig. 2), ${ }^{45}$ in which the repeating unit features a stable 18 valence electron (VE) metallocene, the cobaltocene units in neutral PCE possess 19 VEs. Upon oxidation to the polycationic form, $[\mathrm{PCE}]^{\mathrm{n}+}$, which features $18 \mathrm{VE}$ cobaltocenium units, the resulting polyelectrolyte is air- and moisture-stable with a variety of counter-anions. ${ }^{43}$ The solubility of $[\mathrm{PCE}]^{\mathrm{n}+}$ depends on the nature of these anions; for example, $[\mathrm{PCE}][\mathrm{Cl}]_{\mathrm{n}}$ and $[\mathrm{PCE}]\left[\mathrm{NO}_{3}\right]_{\mathrm{n}}$ are water soluble, ${ }^{43}$ while $[\mathrm{PCE}][\mathrm{OTf}]_{\mathrm{n}}$ exhibits higher solubility in organic solvents, such as THF and MeOH. ${ }^{46}$

Using this cobalt-containing polyelectrolyte, we have also recently reported the first example of a high molar mass 'chiral polymetallocene', which was synthesized via templating of the $[\mathrm{PCE}]^{\mathrm{n}+}$ polyelectrolyte with deoxyribonucleic acid (DNA) of ca. 2000 base pairs in water (Fig. 2) ${ }^{47}$ The resulting [PCE][DNA] complex apparently exhibits strong electrostatic interactions between the anionic phosphodiester groups on the DNA backbone and the cationic cobaltocenium units in the main chain of [PCE $]^{\mathrm{n}+}$, which was found to have taken on a chiral conformation as a result of embedding in the minor or major groove of the DNA double helix. Unfortunately, the poor solubility of the DNA complexes in common solvents substantially limited further investigation and the applicability of these chiral materials.

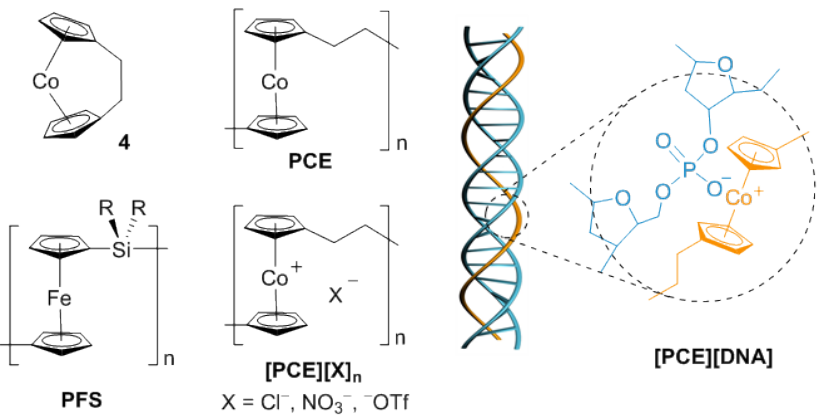

Figure 2. Structures of dicarba[2]cobaltocenophane $\mathbf{4}$, poly(cobaltocenylethylene) poly(cobaltoceniumethylene) polyferrocenylsilane (PFS) and [PCE][DNA] bioconjugate.

'Ionic self-assembly', described as the cooperative assembly of charged surfactants and oppositely charged building blocks, is a well-established method for the creation of functional materials. ${ }^{48-50}$ Of particular interest is the cooperative electrostatic surfactant binding to oppositely charged polyelectrolytes..$^{51-52} \mathrm{~N}$-acyl-amino acid chiral anionic surfactants (which feature a tetrahedral chiral carbon center at a position adjacent to the anionic carboxylate functional group, Fig. 3) ${ }^{53}$ have been intensively studied as building blocks for chiral liquid crystals,54-55 and recently as templates for chiral mesoporous materials. ${ }^{56-57}$ Herein, we report the formation of readily soluble chiral complexes of $[\mathrm{PCE}]^{\mathrm{n}+}$ using these amino acid-derived chiral anionic surfactants as counter anions. We also demonstrate the self-assembly of these chiral complexes into structures on the micron lengthscale which display morphologies reflecting the chirality of the surfactant.

\section{RESULTS AND DISCUSSION}

\section{Complexation of PCE with Chiral Surfactants}

Facile anion exchange in side-chain cobaltoceniumcontaining metallopolymers has been demonstrated by Tang et al.,58 and has recently been utilized to synthesize polymer/antibiotic bioconjugates via ion-pairing of the carboxylate functional group of $\beta$-lactam antibiotics and pendent polymer cobaltocenium units. ${ }^{59}$ Upon coulombic association of $\mathrm{N}$-acyl-amino acid derived chiral anionic surfactants with cationic repeating units of $[\mathrm{PCE}]^{\mathrm{n}+}$, the proximity of the cobaltocenium units within the polymer main chain to the asymmetric center is expected to favour chiral transcription from the surfactant to the polymer.

With this in mind, we employed both enantiomers of two chiral surfactants: $N$-palmitoyl-L-alanine $\left(\mathrm{C}_{16}\right.$-L-Ala) and $\mathrm{N}$-palmitoyl-D-alanine $\left(\mathrm{C}_{16}\right.$-D-Ala), and $\mathrm{N}$-palmitoyl-Lphenylalanine (C 16 -L-Phe) and $N$-palmitoyl-Dphenylalanine ( $\mathrm{C}_{16}$-D-Phe) (Fig. 3) in the chiral complexation of $[\mathrm{PCE}]^{\mathrm{n}+}$. 

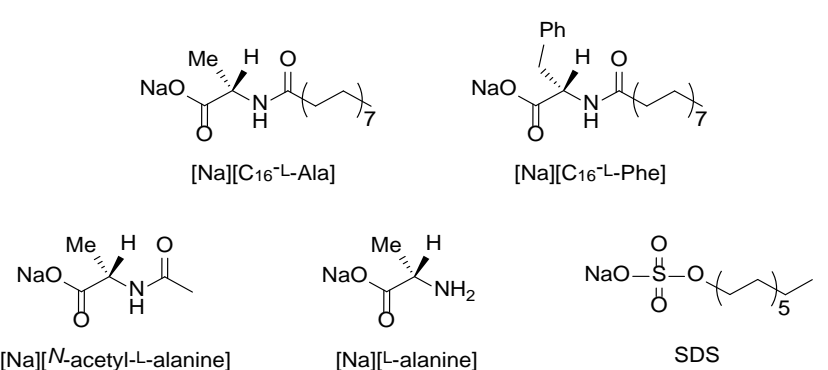

[Na] $[N$-acetyl-L-alanine]

[Na][L-alanine]

SDS

Figure 3. Sodium salts of anionic $N$-acyl-amino acid chiral surfactants, $N$-acetyl-alanine and alanine (L-enantiomers), and sodium dodecyl sulphate.

Neutral PCE was prepared via the thermal ring-opening polymerization of dicarba[2] cobaltocenophane $\mathbf{4}$ (Scheme 1). ${ }^{43}$ The synthesis of monomer $\mathbf{4}$ has been subject to recent improvements, resulting in substantially higher yields ( $37 \%$ vs ca. $10 \%$, see experimental section). The $[\mathrm{PCE}]\left[\mathrm{A}^{*}\right]_{\mathrm{n}}$ (A* represents a chiral anionic surfactant) complexes were subsequently synthesized by oxidation of neutral PCE with atmospheric oxygen in solutions of the respective chiral anionic surfactant as the sodium salt (ca. 2.0 eq. in a mixture of water, ethanol and THF) (Scheme 1). After vigorous stirring for $48 \mathrm{~h}$, the mixture was filtered to remove any remaining solid and gel-like products, which were ascribed to crosslinked PCE formed during the thermal ROP process. ${ }^{43}$ Dialysis of the resulting yellow solution was performed against deionized water and ethanol alternately (Fig. S1) to remove the excess surfactant, small molecule residues and any oligomeric $[\mathrm{PCE}]^{\mathrm{n}+}$ derivatives. $[\mathrm{PCE}]\left[\mathrm{A}^{*}\right]_{\mathrm{n}}$ complexes were obtained in ca. $40 \%$ yield after drying under vacuum. The ${ }^{1} \mathrm{H}$ NMR spectrum of [PCE] $\left[\mathrm{C}_{16}-\mathrm{L}-\mathrm{Ala}\right]_{\mathrm{n}}$ (shown in Fig. S2) indicates the complexation of cobaltocenium units to surfactant anions in a 1:1 ratio.

Scheme 1. Synthesis and thermal ring-opening polymerization of dicarba[2] cobaltocenophane 4, followed by oxidation in the presence of chiral anionic surfactants to yield $[\mathrm{PCE}]\left[\mathrm{A}^{*}\right]_{\mathrm{n}}$ complexes.

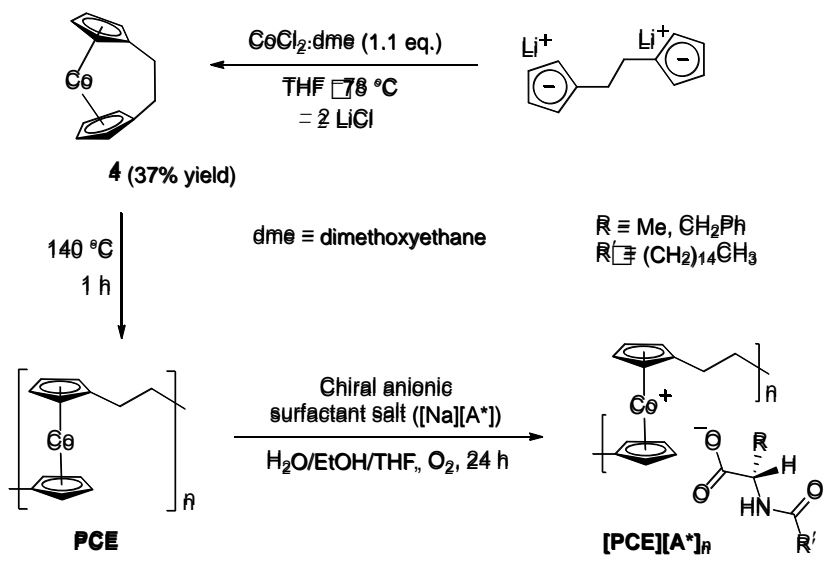

The $[\mathrm{PCE}]\left[\mathrm{A}^{*}\right]_{\mathrm{n}}$ complexes were found to be readily soluble in common organic solvents such as methanol, ethanol and THF, but insoluble in water (Fig. S1). This is indicative of a strong coulombic association between cationic cobaltocenium units of $[\mathrm{PCE}]^{\mathrm{n}+}$ and the carboxylate moiety of the chiral surfactant anions, with effective shielding of the ion pairs by the aliphatic tails of the surfactants. We propose that the resulting structure of these complexes is similar to that of brush-like amphiphilic polymers, ${ }^{60-61}$ but with the brush component (surfactant) linked to the polymer main chain by coulombic rather than covalent interactions. It was found that without removing the base $\left(\mathrm{OH}^{-}\right)$generated during the oxidation process, cleavage of the cobaltocenium units occurred, as has previously been reported. ${ }^{62}$ This decomposition was observed to be more significant upon increasing the reaction concentration, or by replacement of the chiral surfactants with simple carboxylates, such as sodium acetate and sodium dodecanoate (SDS, Fig. 3).

\section{Origin of Chirality in PCE Complexes}

The chirality of the $[\mathrm{PCE}]\left[\mathrm{A}^{*}\right]_{\mathrm{n}}$ complexes in ethanolic solution was studied by circular dichroism (CD) (Fig. 4). [PCE $]\left[\mathrm{C}_{16}-\mathrm{L}-\mathrm{Ala}\right]_{\mathrm{n}}$ (Fig. 4a, red line) showed an intense negative $C D$ response below $240 \mathrm{~nm}$, which was assigned to absorption of the chiral [ $\mathrm{C}_{16}$-L-Ala] ${ }^{-}$anions (Fig. S3). ${ }^{63}$ In the absorption region of $250-300 \mathrm{~nm}$, corresponding to the charge transfer band of cobaltocenium units within $[P C E]^{n+43,64}$ the $C D$ response of the $[\mathrm{PCE}]\left[\mathrm{C}_{16}-\mathrm{L}-\mathrm{Ala}\right]_{\mathrm{n}}$ complex showed a negative maximum and then positive maximum (Cotton effect) as the absorption wavelength decreased. The CD spectrum of the [PCE][C $16-\mathrm{D}-\mathrm{Ala}]_{\mathrm{n}}$ complex exhibited an exact mirror-image to that of its Lenantiomer (Fig. 4a, blue line).
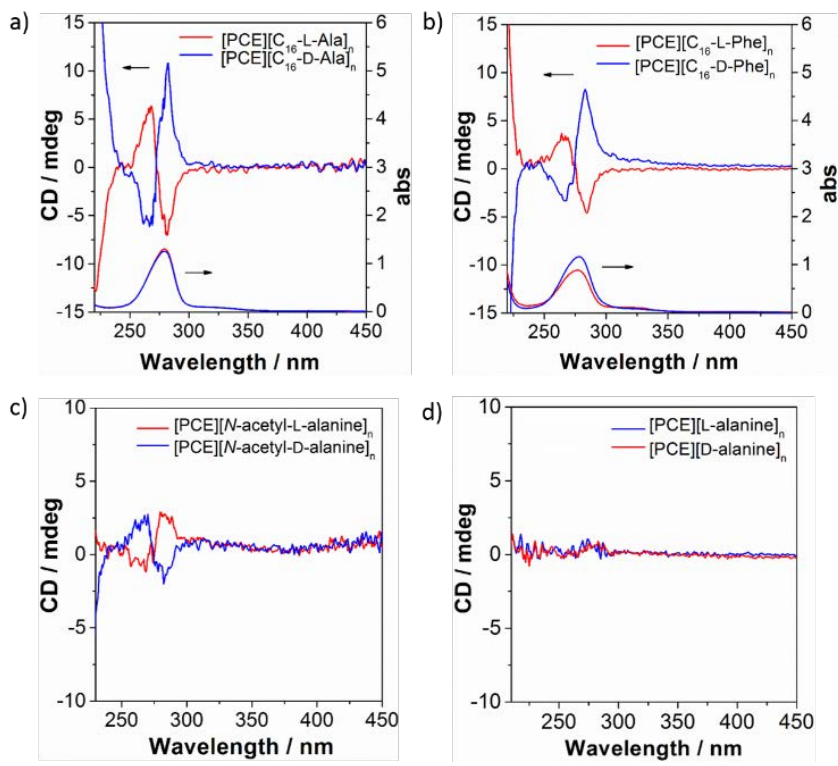

Figure 4. $\mathrm{CD}$ and UV-vis spectra of complexes formed by

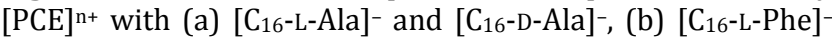
and $\left[\mathrm{C}_{16} \text {-D-Phe }\right]^{-}$, (c) $[\mathrm{N} \text {-acetyl-L-alanine }]^{-}$and $[\mathrm{N}$-acetyl-Dalanine $]^{-}$, and (d) [L-alanine $]^{-}$and [D-alanine $]^{-}$, all at $0.5 \mathrm{mg}$ $\mathrm{mL}^{-1}$ in $\mathrm{EtOH}$.

The observation of equal but opposite split Cotton effects around $270 \mathrm{~nm}$ for the $\mathrm{C}_{16}$-D-Ala and $\mathrm{C}_{16}-\mathrm{L}-\mathrm{Ala}$ complexes of $[\mathrm{PCE}]^{\mathrm{n}+}$ indicates that the alanine-based asymmetric center within these surfactants transcribes chirality to the entire length of the metallopolymer, by imposing an asymmetric conformation on the ethylenic linker (Pfeiffer effect). ${ }^{65-67}$ This affords the chiral space for a unique example of Exciton Coupling (EC) between the chromophoric $\left[\mathrm{CoCp}_{2}\right]^{+}$units, where the electronic 
transition moments of these chromophores interact spatially so that the energy level of the excited states split. ${ }^{68-69}$ EC is usually observed in axially chiral biarylic systems (such as 1,1'-bi-2-naphthols), in chiral vicinal diols substituted with identical chromophores, and in macromolecular complexes such as DNA-porphyrin conjugates. ${ }^{70-71}$ Interestingly, together with the previously reported [PCE][DNA] complex (Fig. 2), these can be considered as novel combinations of Pfeiffer effects ${ }^{69}$ and EC chromophores where the chirality of the DNA or the alanine-based surfactant is transferred to the whole metallopolymer. Variable temperature CD experiments on $[\mathrm{PCE}]\left[\mathrm{C}_{16}-\mathrm{L}-\mathrm{Ala}\right]_{\mathrm{n}}$ in ethanol revealed that the chiral transfer (i.e. the magnitude of the CD response) from the surfactant to the metallopolymer increases as the temperature is lowered (Figs. S4 and S5).

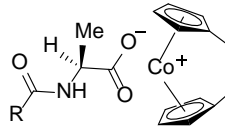

$\left.{ }^{4}\right]\left[\mathrm{C}_{16}{ }^{- \text {L-Ala }]}\right.$

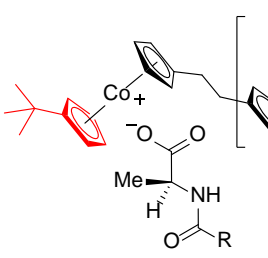

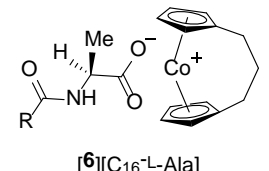

$[5]\left[C_{16}\right.$-L-Ala]

$[6]\left[C_{16}\right.$-L-Ala $]$

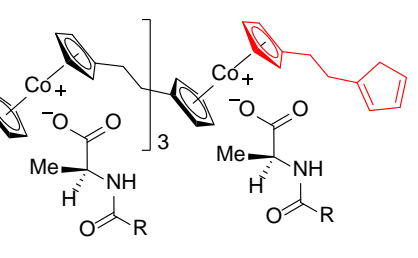

[OCE $\left.{ }_{5}\right]\left[\mathrm{C}_{16}{ }^{-\mathrm{L}-\mathrm{Ala}}\right]_{5}$

$$
\mathrm{R}=\left(\mathrm{CH}_{2}\right){ }_{14} \mathrm{CH}_{3}
$$

Figure 5. Complexes of monomeric cobaltocene derivatives $\mathbf{4}$, 5 and 6 with $\left[\mathrm{C}_{16}-\mathrm{L}-\mathrm{Ala}\right]^{-}$, and molecular structure of oligomeric $\left[\mathrm{OCE}_{5}\right]\left[\mathrm{C}_{16} \text {-L-Ala }\right]_{5}$.

To further elucidate the origin of induced chirality of the $[\mathrm{PCE}]\left[\mathrm{A}^{*}\right]_{\mathrm{n}}$ complexes, a number of monomeric cobaltocene derivatives were also subjected to oxidation in the presence of $\left[\mathrm{C}_{16}-\mathrm{L}-\mathrm{Ala}\right]^{-}$and $\left[\mathrm{C}_{16}-\mathrm{D}-\mathrm{Ala}\right]^{-}$. The complexes formed with bis(ethylcyclopentadienyl)cobalt(II) (5, Fig. 5 ) exhibited no Cotton effect over the absorption region of 250-300 nm (the charge transfer band of cobaltocenium) (Fig. S6a). Similarly, the complexes formed by the hydrocarbon-bridged $[n]$ cobaltocenophanes $\left([4]\left[\mathrm{C}_{16}-\mathrm{L} / \mathrm{D}-\right.\right.$ Ala] and [6][C $\mathrm{C}_{16}$-L/D-Ala], Fig. 5), in which the conformation of the hydrocarbon bridge is fixed, showed no evidence of induced chirality (Figs. S6b,c). This provides crucial evidence that the monomeric analogues are not chiral in this regard, and that sufficient polymer backbone length is required for chirality to be expressed. It therefore seems most likely that the induced chirality originates from the polymeric chain adopting a structure which features axially chiral ethylenic $\mathrm{CH}_{2}-\mathrm{CH}_{2}$ bridges (where the dihedral angle replicates the asymmetry along the polymer chain - see Fig. 6). To test this hypothesis, oligo(cobaltocenylethylene) with 5 repeating units, OCE5 (Fig. S7), ${ }^{43}$ was synthesized and subjected to oxidation and complexation with the chiral anionic surfactants (Fig. 5). The resulting $\left[\mathrm{OCE}_{5}\right]\left[\mathrm{A}^{*}\right]_{5}$ complexes exhibited $\mathrm{CD}$ spectra analogous to the [PCE] $\left[A^{*}\right]_{n}$ complexes; i.e. featuring two sets of Cotton effects with opposite signs in the absorption band of $[\mathrm{PCE}]^{\mathrm{n}+}$, and mirror-image signals for the enantiomers (Fig. S8). However, the Cotton effects are of dramatically lower intensity when compared to the corresponding polymeric $[\mathrm{PCE}]\left[\mathrm{A}^{*}\right]_{\mathrm{n}}$ complexes, again indicating a strong effect of the length of the polymer backbone. In contrast, the complexes formed by the shorttail $N$-acyl-amino acids, i.e., [PCE] $N$-acetyl-L-alanine $]_{\mathrm{n}}$ and [PCE $][N \text {-acetyl-D-alanine }]_{\mathrm{n}}$, revealed much weaker Cotton effects (Fig. 4c), presumably because the absence of a long alkyl side chain leads to insufficient twisting of the ethylenic $\mathrm{C}-\mathrm{C}$ bonds. This indicates at least that the long tail of the chiral counter anions is important for the transcription of chirality. When even smaller surfactants (L-alanine and D-alanine sodium salts) were employed, decomposition of the material was evident during the oxidation process, probably due to the increase in basicity on employing primary amines, to which cobaltocenium ions are sensitive. ${ }^{62}$ In these cases (L-alanine and Dalanine), no chirality was observed by CD (Fig. 4d). In contrast to former observations on the structure of [PCE][DNA] (Fig. 2), where it was postulated that main chain of $[\mathrm{PCE}]^{\mathrm{n}+}$ adopted a helical conformation due to tight complexation with the DNA strand, here we propose that the axial conformation of each repeat unit $\left(\mathrm{CH}_{2}-\mathrm{Cp}-\right.$ $\mathrm{Co}^{+}-\mathrm{Cp}-\mathrm{CH}_{2}$ ) in the polymer backbone of $[\mathrm{PCE}]\left[\mathrm{A}^{*}\right]$ facilitates the emergence of axial chirality. As a consequence of this axial chirality, an EC signature appears in the CD spectra. Indeed, bisignate (i.e. change of sign within the band) CD signatures, such as those observed for the $[\mathrm{PCE}]\left[\mathrm{C}_{16}-\mathrm{D} / \mathrm{L}-\mathrm{Ala}\right]_{\mathrm{n}}$ complexes at $\lambda>250 \mathrm{~nm}$, occur where two or more strongly absorbing chromophores are located nearby in space within a chiral system.

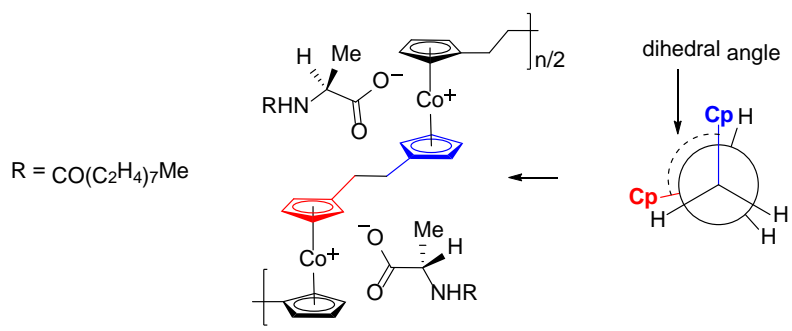

Figure 6. Structure of $[\mathrm{PCE}]\left[\mathrm{C}_{16}-\mathrm{L}-\mathrm{Ala}\right]_{\mathrm{n}}$ with example Newman projection along the $\mathrm{CH}_{2}-\mathrm{CH}_{2}$ axis to demonstrate chirality of the polymer backbone.

Finally, the $[\mathrm{PCE}]\left[\mathrm{C}_{16}-\mathrm{L}-\mathrm{Phe}\right]_{\mathrm{n}}$ and $[\mathrm{PCE}]\left[\mathrm{C}_{16}-\mathrm{D}-\mathrm{Phe}\right]_{\mathrm{n}}$ complexes revealed similar $\mathrm{CD}$ spectra as the $\mathrm{C}_{16}-\mathrm{L} / \mathrm{D}-\mathrm{Ala}$ analogues (Fig. 4b). However, the intensity of the signals was slightly decreased in the $[\mathrm{PCE}]^{\mathrm{n}+}$ absorption band region (Fig. 4b). According to the exciton coupling model, the EC response is sensitive to both the chiral $\mathrm{CH}_{2}-\mathrm{CH}_{2}$ dihedral angle and the interchromophoric distance, which defines the degree of chirality of the polymer backbone. It is therefore likely in the case of the phenylalaninecontaining complexes that the optical purity is the same as that for the alanine analogs, but the CD signal is just weaker on account of a larger dihedral angle between the $\mathrm{Cp}$ rings of each cobaltocenium unit that arise from the greater side-chain bulk $\left(-\mathrm{CH}_{2} \mathrm{C}_{6} \mathrm{H}_{5}\right.$ vs. $\left.-\mathrm{CH}_{3}\right)$ and the close columbic association.

\section{Self-assembly of Chiral PCE Complexes}

In collaboration with Faul and coworkers we have recently reported the preparation of polyferrocenylsilane (PFS, see Fig. 2) polyelectrolyte-surfactant complexes and 
their ionic self-assembly into a rich variety of morphologies in bulk and thin films. ${ }^{72-75}$ In these systems, the PFS polymer backbone was functionalized with pendent ammonium groups, which subsequently interacted coulombically with anionic sulfonate surfactants. Compared to the PFS polyelectrolytesurfactant complexes, the $[\mathrm{PCE}]\left[\mathrm{A}^{*}\right]_{\mathrm{n}}$ complexes exhibit a number of unique features: (i) the surfactant counter anions are chiral, (ii) the charges of the polyelectrolyte are located at the metallocene repeat unit and thus are embedded in the polymer backbone, and (iii) the coulombic pairing is in this case between metallocenium cations and carboxylate anions. With these distinct features, the $[\mathrm{PCE}]\left[\mathrm{A}^{*}\right]_{\mathrm{n}}$ complexes were expected to exhibit interesting behaviour upon self-assembly. 


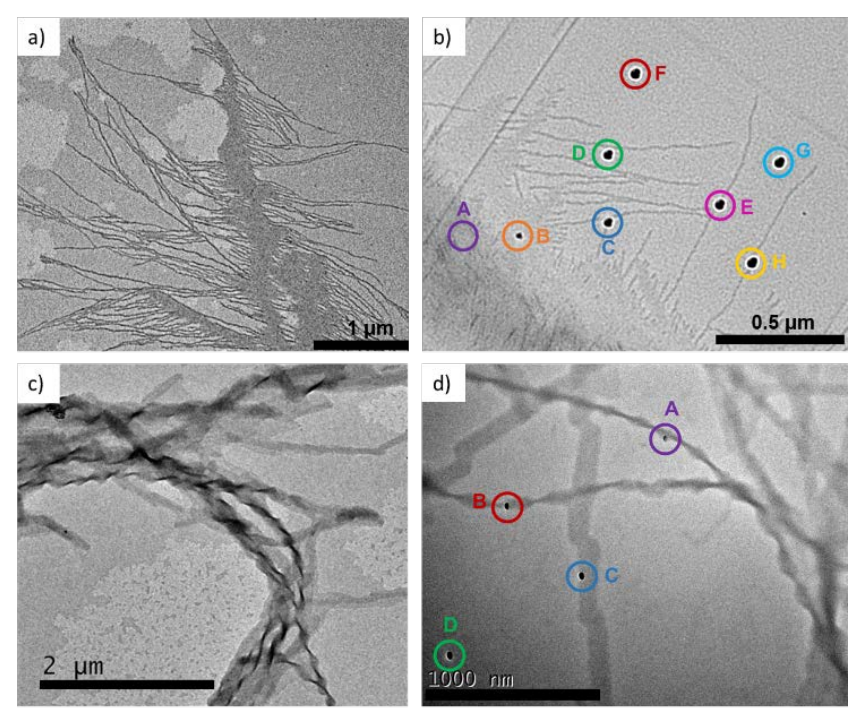

Figure 7. TEM images obtained after drop-casting an aliquot of solutions of [PCE][C 16 -L-Ala $]_{n}$ complex in a) ethanol (ca. 12 $\mathrm{mg} \mathrm{mL}^{-1}$ ) and b) spot EDX analyses of film and fibrous material (drop cast from $12 \mathrm{mg} \mathrm{mL}^{-1}$ ethanolic solution), or c) by drop-casting suspensions of [PCE] $\left[\mathrm{C}_{16}-\mathrm{L}-\mathrm{Ala}\right]_{\mathrm{n}}$ assemblies in water, and d) spot EDX analyses of helices. For detailed EDX analysis of spots see Supporting Information (Figs. S9 and S28).

A variety of imaging techniques were employed to characterise the structure of the $[\mathrm{PCE}]\left[\mathrm{C}_{16}-\mathrm{L}-\mathrm{Ala}\right]_{\mathrm{n}}$ in various solvents, including its self-assembly behaviour. Transmission electron microscopy (TEM) of drop-cast ethanolic solutions of [PCE][C $\left.\mathrm{C}_{16}-\mathrm{L}-\mathrm{Ala}\right]_{\mathrm{n}}$ (ca. $12 \mathrm{mg} \mathrm{mL}^{-1}$ ) revealed the presence of both film and fibrous material (with average width of ca. $6 \mathrm{~nm}$ ) with the latter protruding from the edges of the former (Figs. $7 a$ and 7b). The protrusion of these long fibrils from areas of the TEM grid that are covered by polymer film suggests that fiber formation might be the result of a drying effect. Energydispersive X-ray (EDX) spectroscopy was employed to confirm the presence of cobalt within the film, the fibrils, and even areas of the grid where no material could be visibly identified (see Fig. 7b and Fig. S9 for details). This suggests that the grid is covered in a thin film of [PCE] $\left[\mathrm{C}_{16}\right.$ $\mathrm{L}-\mathrm{Ala}]_{\mathrm{n}}$ which is concentrated into thicker areas of film and fibers upon drying, and only the latter two are of sufficient contrast to be observed by TEM.

Dynamic light scattering (DLS) experiments were performed on an ethanolic solution of [PCE] [ $\left.\mathrm{C}_{16}-\mathrm{L}-\mathrm{Ala}\right]_{\mathrm{n}}$ (ca.

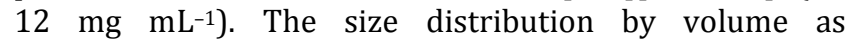
determined by DLS gives a population of hydrodynamic radius $\left(R_{\mathrm{h}}\right) 1.2 \mathrm{~nm}$ (Figs. $\mathrm{S} 10$ and $\left.\mathrm{S} 11\right)$, which is small relative to that expected for $[\mathrm{PCE}]^{\mathrm{n}+}$ macromolecules. ${ }^{43}$ The pseudo-brush polymers afforded by complexation, however, are expected to deviate in shape from the spherical particles for which the diffusion was modelled. The size distribution by intensity (Fig. S12) indicates the presence of a species of $R_{\mathrm{h}}=12.2 \mathrm{~nm}$, which would seem more consistent with the $[\mathrm{PCE}]^{\mathrm{n}+}$ macromolecular species (see Figs. S13 and S14). ${ }^{76-77}$ Regardless, this DLS data affords no evidence to support the existence of multimicron fibers in ethanol solution, which were observed in the dry-state by TEM (Figs. 7a,b).
The association of the polymer and surfactant in solution was analyzed by diffusion ordered spectroscopy (DOSY) NMR (Fig. S15). The [PCE][C $\left.\mathrm{C}_{16}-\mathrm{L}-\mathrm{Ala}\right]_{\mathrm{n}}$ complex is fully soluble in $d_{4}$-methanol, ${ }^{58}$ and the diffusion coefficient of $[\mathrm{PCE}]^{\mathrm{n}+}\left(1.2 \times 10^{-10} \mathrm{~m}^{2} \mathrm{~s}^{-1}\right)$ is significantly smaller than that of the [ $\left.\mathrm{C}_{16}-\mathrm{L}-\mathrm{Ala}\right]^{-}$anions $\left(3.4 \times 10^{-10} \mathrm{~m}^{2} \mathrm{~s}^{-1}\right)$ in this solvent. This indicates that although coulombic interactions between the polyelectrolyte and the surfactant anions are clearly present (resulting in the transfer of chirality as observed by CD spectroscopy), the anions are not tightly bound to $[\mathrm{PCE}]^{\mathrm{n}+}$ when solvated in polar organic solvents. Such ion association has been previously described for cobaltocenium-containing polyelectrolytes, ${ }^{58}$ and supports the DLS data, indicating that fibrous structures are not present in ethanol solution.

In order to probe the crystallinity of the ethanolsoluble complex, wide angle X-ray scattering (WAXS) analysis of $[\mathrm{PCE}]\left[\mathrm{C}_{16}-\mathrm{L}-\mathrm{Ala}\right]_{\mathrm{n}}$ drop cast from ethanol solution was performed. The presence of sharp reflections at $2.8,3.1,3.4,3.8,4.0,4.1,10.2$ and $15.2 \AA$, suggests that the material does indeed exhibit crystalline order (Fig. S16). The structure of the fibers is, at present, unclear, but it is possible that interdigitation of the hydrocarbon tails of the surfactant molecules occurs as the local concentration of the solution increases upon drying.

Small angle X-ray scattering (SAXS) was also performed on ethanolic solutions of [PCE][C 16 -L-Ala $]_{n}$ (four samples were prepared at $18,22.5,33$ and $45 \mathrm{mg} \mathrm{mL}^{-1}$ - see Figs. S17-20), where the scattered intensity (I) observed for these samples in the range of $0.1<Q<0.6$ reflects the simple change in solvent structure on changing the concentration of the suspended particles (Fig. S17). The slope of the loglog plot of intensity $(I)$ vs. scattering vector $(Q)$ in this range $(-1)$ is indicative of thin rods (Fig. S18), although the samples were not sufficiently dilute to result in single particle scattering (Fig. S19).

Differential scanning calorimetry (DSC) was employed to further elucidate the crystalline nature of the [PCE][C $\mathrm{C}_{16}$ L-Ala $]_{n}$ complex (again drop cast from ethanol solution). Cyclic temperature DSC experiments were performed between $-30{ }^{\circ} \mathrm{C}$ and $60{ }^{\circ} \mathrm{C}$, as thermal gravimetric analysis (TGA) revealed the onset of decomposition of the material above $60^{\circ} \mathrm{C}$ (Fig. S21). These cyclic DSC scans consistently revealed two first-order endothermic processes during the heating phase at ca. $16{ }^{\circ} \mathrm{C}$ and $40{ }^{\circ} \mathrm{C}$, followed by two exothermic processes during the cooling phase at ca. $20^{\circ} \mathrm{C}$ and $-4{ }^{\circ} \mathrm{C}$ (Fig. S22). The thermal behavior of the chiral surfactant-paired polymer is significantly different to that of the related chloride-paired [PCE][Cl] $]_{\mathrm{n}}$ polymer and the $\mathrm{Na}\left[\mathrm{C}_{16}-\mathrm{L}-\mathrm{Ala}\right]$ salt. DSC experiments on $[\mathrm{PCE}][\mathrm{Cl}]_{\mathrm{n}}$ revealed only a very small second-order transition at ca. $97^{\circ} \mathrm{C}$ (Fig. S23), which may be assignable to the $T_{\mathrm{g}}$ (glass transition) of the polymer. Despite the absence of a $T_{\mathrm{m}}$ (melt transition) in the thermogram, WAXS analysis of [PCE][Cl] showed some crystalline order, with one broad reflection corresponding to a d-spacing of $4.1 \AA$ (Fig. S24). Unfortunately, attempts to anneal the sample in order to increase its crystallinity (by either thermal annealing at $120^{\circ} \mathrm{C}$, or solvent annealing with $\mathrm{EtOH}$ ) were unsuccessful. Some structural similarity between the chloride- and 
surfactant-paired polymers can be drawn, as the broad reflection at $4.1 \AA$ also appears to feature prominently in the WAXS pattern of the $[\mathrm{PCE}]\left[\mathrm{C}_{16}-\mathrm{L}-\mathrm{Ala}\right]_{\mathrm{n}}$ complex (Fig. S16). The origin of this reflection, however, remains unclear.

Additional investigation into the thermal behavior of the $\mathrm{Na}\left[\mathrm{C}_{16}\right.$-L-Ala] salt was conducted by DSC measurements (Fig. S25), revealing a second-order transition at ca. $38{ }^{\circ} \mathrm{C}$ (perhaps assignable to a $T_{\mathrm{g}}$ associated with the $\mathrm{C}_{16}$ surfactant chains), and a first-order melt transition at ca. $57{ }^{\circ} \mathrm{C}$ (with the reverse processes present in the cooling scan). The WAXS data for this surfactant is displayed in Fig. S26.

After dialysis of a diluted ethanolic solution of

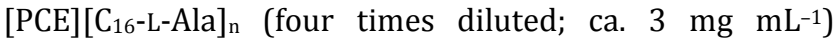
against THF, and subsequently deionized water, for $16 \mathrm{~h}$, the complex precipitated from solution, forming a fine pale yellow suspension. ${ }^{78}$ TEM imaging of dried samples of this suspended material showed the presence of twisted helical structures. The material appears to be composed of a mixture of tightly twisted helices (Fig. 7c, d) and in some cases, larger twisted coils of various sizes (Fig. S27), which assemble into even larger aggregates which are difficult to image via TEM, as a result of their large size and high electron density. The presence of cobalt within these helical structures was confirmed by EDX spectroscopy (see experimental section, Fig. S28).

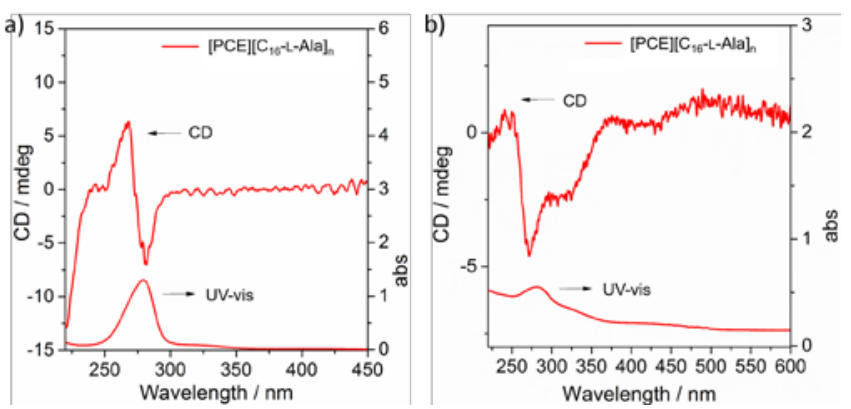

Figure 8. a) Solution state CD and UV-vis spectra of [PCE][C $\mathrm{C}_{16}$ L-Ala]n at $0.5 \mathrm{mg} \mathrm{mL}^{-1}$ in $\mathrm{EtOH}$, and b) solid state CD and UVvis spectra of the $[\mathrm{PCE}]\left[\mathrm{C}_{16}-\mathrm{L}-\mathrm{Ala}\right]_{\mathrm{n}}$ self-assembly product formed in water.

It should be noted that these helical morphologies are distinctly different to those formed by the achiral complex $[\mathrm{PCE}]\left[\mathrm{NO}_{3}\right]_{\mathrm{n}}$ or the $\mathrm{Na}\left[\mathrm{C}_{16}\right.$-L-Ala] surfactant salt alone (Fig. S29a,b respectively), and thus indicate a key influence of chiral complexation on the self-assembly behavior. Furthermore, control experiments showed that these regular helical self-assembled structures were inaccessible when using the analogous achiral PCE/surfactant complex formed by $[\mathrm{PCE}]^{\mathrm{n}+}$ and sodium dodecylsulfate (SDS) (Fig. S30) or an achiral long alkyl-grafted neutral PFS species (Fig. S31). This indicates that the presence of asymmetric centres within the surfactant anions is essential for defined chiral self-assembly. Solid-state CD measurements were performed on a dry sample of the [PCE][C $16-\mathrm{L}-\mathrm{Ala}]_{\mathrm{n}}$ helical self-assembly product (see Fig. S32). The UV response of the material again features an absorption band at 250-300 $\mathrm{nm}$, in the region consistent with cobaltocenium charge transfer in $[\mathrm{PCE}]^{\mathrm{n}+}$ (Fig. 8b) ${ }^{43}$ The CD spectrum of the assembled product exhibits a broad Cotton effect with a negative maximum (multiple features from ca. $400 \mathrm{~nm}$ ) and subsequently a positive maximum as the absorption wavelength decreased to ca. $250 \mathrm{~nm}$ (Fig. 8b). This new CD signature may correspond to another expression of chirality; i.e. the supramolecular organization between each helical polymeric strand (tertiary structure), while the former EC signature of [PCE] $\left[\mathrm{C}_{16}-\mathrm{L}-\mathrm{Ala}\right]_{\mathrm{n}}$ in ethanolic solution (Fig. 8a) described the secondary structure of the brush-like polymer complex. Another feasible explanation for this change in $\mathrm{CD}$ response involves the difference in folding of the polymer chains in ethanol vs. water. It should be noted that the sign of the Cotton effect is the same (i.e. a negative $\mathrm{CD}$ maximum followed by positive $\mathrm{CD}$ maximum upon decreasing wavelength) for both the ethanolic solubilized [PCE][C $16-\mathrm{L}-\mathrm{Ala}]_{\mathrm{n}}$ complex (Fig. 8a) and its aqueous self-assembly product (Fig. 8b), indicating that the handedness of these helical assemblies is inherited from the substituent polymer complex. WAXS analysis of a dry sample of the aqueous [PCE][C $\left.\mathrm{C}_{16}-\mathrm{L}-\mathrm{Ala}\right]_{\mathrm{n}}$ assemblies was performed, indicating a largely amorphous material with weak reflections identified at 4.1 and $3.9 \AA$ (Fig. S33). Again, the first reflection ( $4.1 \AA$ ) also features prominently in the WAXS pattern of the [PCE] $[\mathrm{Cl}]_{\mathrm{n}}$ complex (Fig. S24).

Although the structures formed by self-assembly in water can be clearly identified as helical, it is difficult to determine the "handedness" (direction of twist) of the helices solely by analysis of the TEM images, which only provide a two-dimensional perspective. 

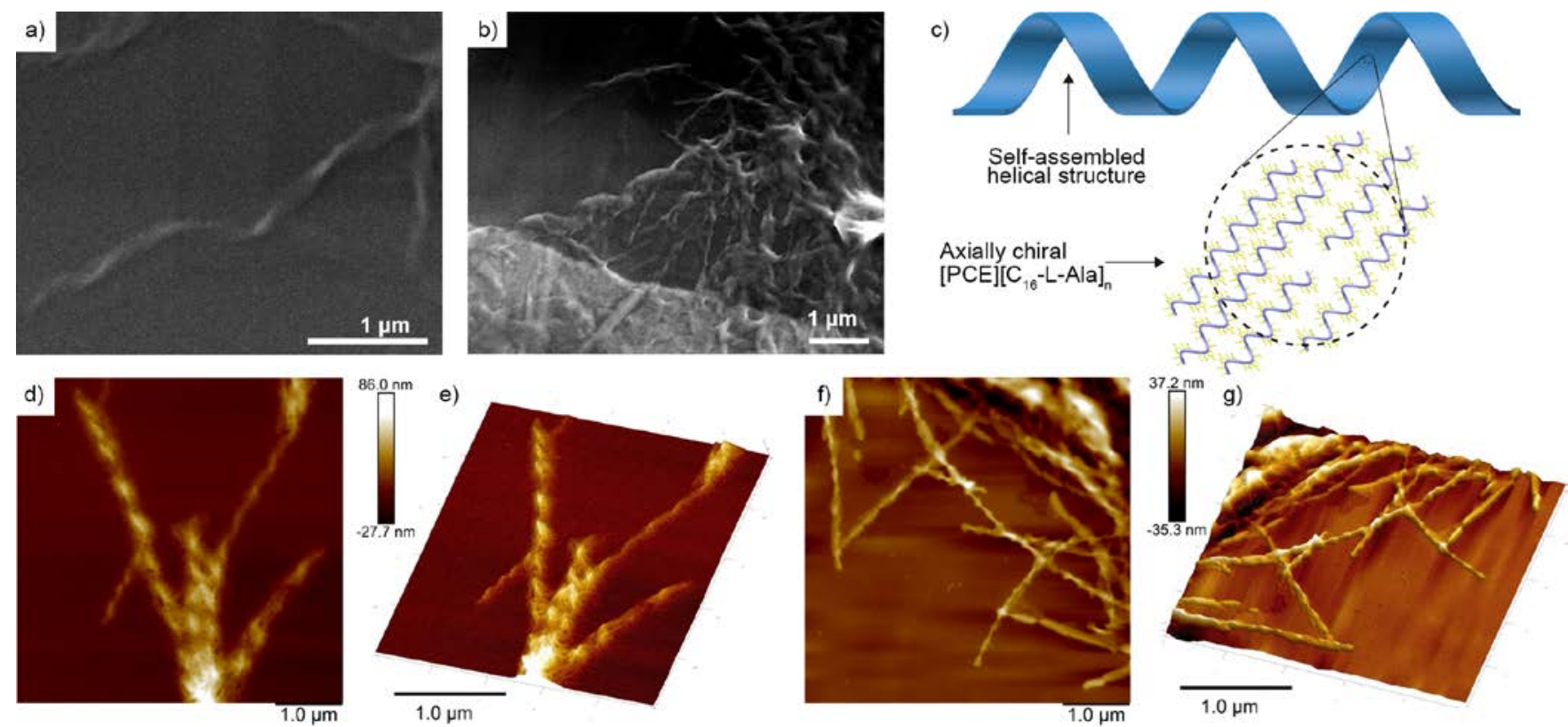

Figure 9. a-b) SEM images obtained after drop-casting an aliquot of suspensions of [PCE][C ${ }_{16}$-L-Ala $]_{n}$ in water on a carbon-coated copper grid and subsequent sputter-coating with Pt/Pd alloy: a) SEM image of an individual helix exhibiting a left-handed twist, b) FE-SEM image of helices and larger coil (lighter sections in image are associated with copper areas of the TEM grid). c) Postulated interdigitation of fatty acid brushes of individual polymer helices to form larger helical assemblies. d-g) AFM height images obtained by drop-casting an aliquot of suspensions of [PCE] $\left[\mathrm{C}_{16}-\mathrm{L}-\mathrm{Ala}\right]_{\mathrm{n}}$ in water onto: d) freshly cleaved mica (3D view of AFM image shown in e) with 5x exaggeration of Z-ratio for clarity) showing individual helices with some aggregation, and f), a carboncoated copper grid (3D view of AFM height images shown in g), with 5x exaggeration of Z-ratio for clarity) showing aggregation of helical material.

Scanning electron microscopy (SEM) and field emission SEM (FE-SEM) was employed after sputter coating of the TEM grids with Pt/Pd alloy, to visualize the superhelices in three dimensions. It is evident from SEM images of individual helices which are many microns in length (e.g. Fig. 9a) that a left-handed twist is present within the helices formed by the [PCE][C $\left.\mathrm{C}_{16}-\mathrm{L}-\mathrm{Ala}\right]_{\mathrm{n}}$ complex. In addition, all other helices which were identifiable by SEM could also be assigned as left-handed, indicating that enantiomeric purity of the molecular surfactant anion was being transferred not only to the macromolecular complexes, but also to structures on a much larger length scale. Fig. $9 \mathrm{~b}$ shows a collection of these helices at the edge of a large section of aggregated material, as well as a larger coil (exhibiting both increased pitch length and diameter). Additional representative SEM and FE-SEM images (see Supporting Information, Figs. S34 and S35) show areas of aggregation in which twisted material has assembled en masse to form much larger structures. The precipitation of material from solution upon dialysis with water is thought to be driven by association of the hydrophobic hydrocarbon surfactant tail ends which surround the metallopolymer chain. Although the organization of [PCE $]\left[\mathrm{C}_{16}-\mathrm{L}-\mathrm{Ala}\right]_{\mathrm{n}}$ chains within these helical structures is not yet fully understood, it is likely that the polymer chains align side by side, and the axial chirality of each chain translates to a further axial chirality, or helicity, of the resulting assembly (Fig. 9c). The left-handed twist of the $[\mathrm{PCE}]\left[\mathrm{C}_{16}-\mathrm{L}-\mathrm{Ala}\right]_{\mathrm{n}}$ helices was also confirmed by Atomic Force Microscopy (AFM). Imaging was performed on samples drop cast onto both mica (Figs. 9d,e) and carboncoated copper grids (Figs. 9f,g). The three-dimensional height profile shown in Fig. 9e clearly shows the lefthanded twist of each helix. Figs. $9 f$ and $9 \mathrm{~g}$ again demonstrate the aggregation of individual helices to form larger networks (additional representative AFM height images of helices and their aggregates are shown in Figs. S36 and S37).

\section{SUMMARY}

We have demonstrated the formation of soluble chiral $[\mathrm{PCE}]^{\mathrm{n}+}$ complexes through the ion-pairing of a polyelectrolytic metallopolymer with chiral surfactant counter anions during oxidation, and the solution selfassembly of [PCE][C $16-\mathrm{L}-\mathrm{Ala}]_{\mathrm{n}}$ into helical structures which reflect the molecular chirality of the complex. The novel transcription of chirality, where the surfactant chirality induces an exciton coupling response which is dependent on the ethylenic dihedral angle and the intercobaltocenium distance in the $[\mathrm{PCE}]^{\mathrm{n}+}$ backbone, inspires a new strategy to prepare chiral macromolecular systems. The versatile self-assembly in different solvents to form hierarchical superhelical structures also implies a wide range of potential applications of these complexes as chiral materials. Future work will focus on theoretical calculations to verify the exciton coupling model of chirality with these complexes, the development of controlled self-assembly methods to reduce aggregation in aqueous solution, and the synthesis and hierarchical selfassembly of chiral complexes derived from PCE block 
copolymers. ${ }^{46}$

\section{EXPERIMENTAL SECTION}

L-alanine, D-alanine, $N$-acetyl-L-alanine, $N$-acetyl-Dalanine, sodium acetate, sodium decanoate, bis(ethylcyclopentadienyl)cobalt(II), and sodium dodecylsulfate (SDS) (all purchased from Sigma-Aldrich) and $\mathrm{CoCl}_{2}$ (purchased from Strem Chemicals) were used without further purification. The fly trap ligand $\mathrm{Li}_{2}\left[\left(\mathrm{C}_{5} \mathrm{H}_{4}\right)_{2}\left(\mathrm{CH}_{2}\right)_{2}\right],{ }^{79} \quad$ tricarba[3]cobaltocenophane, ${ }^{44}$ $(\mathrm{PCE})^{43},[\mathrm{PCE}][\mathrm{Cl}]_{\mathrm{n}}{ }^{43}$ and $[\mathrm{PCE}]\left[\mathrm{NO}_{3}\right]_{\mathrm{n}}{ }^{43}$ were prepared according to literature procedures. $\mathrm{CoCl}_{2} \cdot \mathrm{dme}$ was prepared by refluxing $\mathrm{CoCl}_{2}$ in neat dimethoxyethane. Dicarba[2]cobaltocenophane was prepared according to a modified synthesis (see below). $\mathrm{C}_{16}$-L-Ala, $\mathrm{C}_{16}$-D-Ala, $\mathrm{C}_{16}$-LPhe and $\mathrm{C}_{16}$-D-Phe were synthesized according to a literature procedure..$^{53}$ L-alanine, D-alanine, $N$-acetyl-Lalanine, $N$-acetyl-D-alanine, $\mathrm{C}_{16}$-L-Ala, $\mathrm{C}_{16}$-D-Ala, $\mathrm{C}_{16}$-L-Phe and $\mathrm{C}_{16}$-D-Phe were transformed to their sodium salts by reaction with one equivalent of sodium hydroxide in aqueous solution ( $0.1 \mathrm{~mol} \mathrm{~L}^{-1}$ ). Dodecyl-grafted PFS (PFS$\mathrm{C}_{12}$ ) was prepared according to a literature procedure. ${ }^{80}$

Dialysis was performed using Spectra/Por ${ }^{\circledR}$ molecularporous membrane tubing (MWCO $8000 \mathrm{~g} \mathrm{~mol}^{-1}$ ), into which solutions were transferred and sealed with dialysis clips. Dialysis against any particular solvent was performed for $>6$ hours.

All syntheses and manipulations of neutral cobaltocene-containing compounds were carried out under an inert atmosphere of dinitrogen or argon using standard Schlenk line of glovebox techniques (MBraun glovebox MB150G-B maintained at $<0.1$ ppm $\mathrm{H}_{2} \mathrm{O}$ and $<$ $0.1 \mathrm{ppm} \mathrm{O}_{2}$. Dry THF was distilled under dinitrogen from $\mathrm{Na}$ /benzophenone immediately prior to use. Dry hexanes was obtained from a Grubbs-type solvent system employing alumina and supported copper columns. ${ }^{81} 1,2-$ Dimethoxyethane was dried over $\mathrm{CaH}_{2}$ and distilled before use.

Photoirradiation experiments were carried out using Pyrex-glass-filtered emission $(\lambda>310 \mathrm{~nm})$ from a $125 \mathrm{~W}$ high pressure Hg vapour lamp (Photochemical Reactors Ltd.).

${ }^{1} \mathrm{H}$ NMR spectra were recorded at ambient temperature on a JEOL ECS NMR $300 \mathrm{MHz}$ spectrometer or Varian NMR $500 \mathrm{MHz}$ spectrometer, reported relative to external tetramethylsilane, and referenced to the most downfield residual solvent resonance ( $\left.\mathrm{CD}_{3} \mathrm{OD}: \delta_{\mathrm{H}} 3.31 \mathrm{ppm}\right)$. Diffusion ordered spectroscopy (DOSY) NMR experiments were carried out on a Varian NMR $500 \mathrm{MHz}$ spectrometer. The diffusion delay set to $80 \mathrm{~ms}$, and DOSY NMR spectra were processed with DOSYToolbox. ${ }^{82}$

Circular dichroism (CD) spectra were obtained using a JASCO J-815 spectrophotometer. Solution samples were prepared in $1 \mathrm{~mm}$ path-length quartz cuvettes, and solid samples (ca. $5 \mathrm{mg}$ ) were placed between two quartz plates. Measurements were performed at room temperature (ca. $25^{\circ} \mathrm{C}$ ) under constant nitrogen flow, which was used to purge the ozone generated by the light source of the instrument. Three scans were averaged per spectrum to improve the signal-to-noise ratio, operating from 200 to
$500 \mathrm{~nm}$ at a scan rate of $100 \mathrm{~nm} \mathrm{~min}-1$ and a bandwidth of $1 \mathrm{~nm}$.

UV-vis spectra were obtained on a Thermo Scientific NanoDrop 2000c UV-vis spectrophotometer, operating from 200 to $500 \mathrm{~nm}$ at a scan rate of $100 \mathrm{~nm} \mathrm{~min}^{-1}$.

Differential scanning calorimetry (DSC) was performed on a TA Instruments Q100 calorimeter at a scan rate of

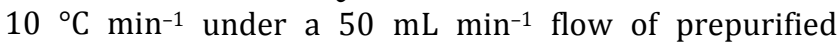
nitrogen. Samples were placed in hermetic aluminium pans and weighed using a XT220A Precisa microbalance. TGA was measured on a Thermal Advantage TGAQ500 at $10{ }^{\circ} \mathrm{C} \mathrm{min}-1$ under $\mathrm{N}_{2}$. DSC and TGA scans were analysed using the TA Instruments software Universal Analysis 2000 version 4.5 a build 4.5.0.5.

Transmission electron microscopy (TEM) images were obtained on a JEOL1200EX II microscope operating at 120 $\mathrm{kV}$ and equipped with an SIS MegaViewIII digital camera. Samples were prepared by placing one drop (ca. $10 \mu \mathrm{L}$ ) of solution on a carbon-coated copper grid (Agar Scientific, square 600 mesh), which was placed on a piece of filter paper to remove excess solvent. No staining of the samples was necessary. Energy dispersive X-ray (EDX) spectroscopy was performed using an Aztec X-Max $80 \mathrm{~mm}^{2}$ silicon drift detector (Oxford Instruments) attached to a JEOL2100F field emission scanning transmission electron microscope (Chemistry Imaging Facility at University of Bristol).

Atomic force microscopy analyses were performed under ambient conditions using a Bruker Multimode VIII atomic force microscope equipped with a ScanAsyst-HR fast scanning module and a ScanAsyst-Air-HR probe (tip radius, $2 \mathrm{~nm}$ ), utilizing peak force feedback control. Samples were drop-cast onto either carbon-coated copper TEM grids or freshly cleaved mica surfaces (Ruby muscovite sheets, $100 \mathrm{~mm}$ x $20 \mathrm{~mm}$ x $0.15 \mathrm{~mm}$, Agar Scientific). Images were recorded after drying the sample under ambient conditions and processed using Bruker Nanoscope Analysis software.

Scanning Electron Microscopy was performed using a JEOL JSM 6330F Field Emission Scanning Electron Microscope or a JEOL JSM 5600LV Scanning Electron Microscope. Samples were drop cast onto carbon-coated copper grids and subsequently sputter-coated with platinum/palladium alloy.

Dynamic Light Scattering (DLS) experiments were performed to determine hydrodynamic radii of polymeric species. Samples (2 $\mathrm{mL}$ ) of different polymer solutions ([PCE][C $16-\mathrm{L}-\mathrm{Ala}]_{\mathrm{n}}: 12 \mathrm{mg} \mathrm{mL}^{-1}, \mathrm{EtOH} ;[\mathrm{PCE}][\mathrm{Cl}]_{\mathrm{n}}: 2 \mathrm{mg} \mathrm{mL}^{-}$ $\left.1, \mathrm{H}_{2} \mathrm{O}\right)$ were placed into optical glass cuvettes $(10.0 \mathrm{~mm}$ path length). The measurements were performed on a Malvern Instruments Zetasizer Nano S using a $5 \mathrm{~mW}$ He-Ne laser $(633 \mathrm{~nm})$ at $25{ }^{\circ} \mathrm{C}$. The correlation function was acquired in real time and analyzed with a function capable of modelling multiple exponentials. This process enabled the diffusion coefficients for the component particles to be extracted, and these were subsequently expressed as effective hydrodynamic radius, by volume and intensity, using the Stokes-Einstein relationship.

Wide angle X-ray scattering (WAXS) experiments were 
carried out on a D8 Advance diffractometer fitted with an $0.6 \mathrm{~mm}$ fixed divergence slit, knife-edge collimator and a LynxEye area detector using $\mathrm{Cu} \mathrm{K} \alpha$ radiation $(\lambda=1.5418$ $\AA$ ). Data was collected between 5 and 50 degrees $2 \theta$ in $\theta / 2 \theta$ mode with a step width of $0.5^{\circ}$. Samples were prepared by the loading of solid samples (or by dropcasting of samples in solution) onto a silicon wafer prior to analysis.

The solution X-ray diffraction data was taken using a Ganesha small angle X-ray scattering apparatus (SAXSLAB,

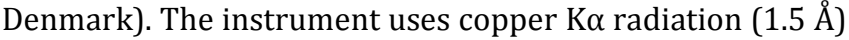
and the scattering pattern is detected on a 2-dimensional Pilatus 300K X-Ray Detector (Dectris, Switzerland). Prior to measurement, the absolute intensity scale was calibrated using a sample of ethanol. Samples were prepared at known concentrations in ethanol and sealed into $1.5 \mathrm{~mm}$ diameter quartz capillary tubes (Capillary Tube Supplies, Cornwall, UK) with epoxy resin. The thickness of each capillary was measured exactly by scanning the X-ray beam across the sample and observing the full-width at half-maximum of the transmitted intensity using a pin diode. All samples were then measured at two sample to detector distances $(1400 \mathrm{~mm}$ and $350 \mathrm{~mm}$ ) and measurements of the corresponding empty capillary and solvent background were subtracted prior to fitting. The instrument was evacuated during measurements to reduce air scattering.

Modified synthesis of dicarba[2]cobaltocenophane (4): $\mathrm{CoCl}_{2} \cdot$ dme (1.42 g, $\left.6.47 \mathrm{mmol}\right)$ and the "fly-trap" ligand $\mathrm{Li}_{2}\left[\left(\mathrm{C}_{5} \mathrm{H}_{4}\right)_{2}\left(\mathrm{CH}_{2}\right)_{2}\right] \quad(1.0 \mathrm{~g}, 5.88 \mathrm{mmol})$ were separately dissolved in dry THF ( $2 \times 125 \mathrm{~mL})$, and both suspensions were cooled to $-78{ }^{\circ} \mathrm{C}$ with constant stirring. The ligand/THF suspension was added rapidly via cannula to the $\mathrm{CoCl}_{2} \cdot \mathrm{dme}$ suspension, and the reaction mixture was stirred and allowed to warm to room temperature over a period of $16 \mathrm{~h}$. The solvent was removed under reduced pressure and the residue was extracted with $n$-hexanes to give a dark red/purple solution, which was filtered through Celite (1" $\times 4$ ") to remove LiCl. All volatiles were removed under reduced pressure and the resulting dark purple solid was purified by sublimation $\left(40^{\circ} \mathrm{C} /-78^{\circ} \mathrm{C}, 5.0\right.$ $\times 10^{-2}$ mbar) to afford the product (4) in $37 \%$ yield. This compares to a yield of ca. $10 \%$ via the previously reported procedure. ${ }^{44}$

Synthesis of [PCE][A*] : In a $30 \mathrm{~mL}$ glass vial, PCE (14 $\mathrm{mg}, 0.093 \mathrm{mmol}$ of cobaltocene units) was combined with an aqueous solution of $\mathrm{Na}\left[\mathrm{A}^{*}\right]$ (1.4 mL, $0.1 \mathrm{~mol} \mathrm{~L}^{-1}$, ca. 2 eq.) $\left(\mathrm{A}^{*}=\mathrm{C}_{16}\right.$-L-Ala, $\mathrm{C}_{16}$-D-Ala, $\mathrm{C}_{16}$-L-Phe, $\mathrm{C}_{16}$-D-Phe, $\mathrm{N}$-acetyl-Lalanine, $N$-acetyl-D-alanine, L-alanine, D-alanine, sodium acetate, sodium decanoate or SDS). To aid the dissolution of PCE and the resulting products, ethanol $(10 \mathrm{~mL})$ and THF ( $5 \mathrm{~mL}$ ) were also added. The mixtures were stirred in the presence of atmospheric oxygen for $48 \mathrm{~h}$, during which time the black PCE was gradually consumed, yielding a yellow suspension. Ethanol $(10 \mathrm{~mL})$ was subsequently added and the suspension was filtered to remove the remaining solid material and gel-like products (likely to be crosslinked PCE formed during thermal ROP). The clear yellow filtrates were transferred into a dialysis bag (MWCO $8000 \mathrm{~g} \mathrm{~mol}^{-1}$ ) and subjected to dialysis against alternating deionized water and ethanol to remove excess surfactant, $\mathrm{NaOH}$ generated during oxidation, and $[\mathrm{PCE}]^{\mathrm{n}+}$ oligomer derivatives. Without prompt dialysis against water and ethanol after the initial complexation/oxidation, the yellow filtrates were unstable and decomposed resulting in dark brown solutions. Decomposition is attributable to reaction of the cobaltocenium units with $\mathrm{NaOH}$ generated during the oxidation process $\left(2 \mathrm{H}_{2} \mathrm{O}+\mathrm{O}_{2}+\right.$ $4 \mathrm{e}^{-} \rightarrow 4 \mathrm{OH}^{-}$), as has been previously described. ${ }^{62}$

The resulting yellow solutions were concentrated by evaporation of solvents under a flow of $\mathrm{N}_{2}$ gas and subsequently dried under vacuum at room temperature (ca. 40\% yield). [PCE] $\left[\mathrm{C}_{16} \text {-L-Ala }\right]_{n}{ }^{1} \mathrm{H}$ NMR $\left(\mathrm{CD}_{3} \mathrm{OD}, 500\right.$ $\mathrm{MHz}): \delta(\mathrm{ppm}) 0.90\left(\mathrm{t}, 3 \mathrm{H},\left[\mathrm{C}_{16}-\mathrm{L}-\mathrm{Ala}\right],-\left(\mathrm{CH}_{2}\right)_{14} \mathrm{CH}_{3}\right), 1.29$ (br m, $24 \mathrm{H},\left[\mathrm{C}_{16}\right.$-L-Ala], $\left.\left(\mathrm{CH}_{2}\right)_{12} \mathrm{CH}_{3}\right), 1.60$ (br m, $2 \mathrm{H},\left[\mathrm{C}_{16}\right.$-LAla], $\left.\mathrm{CH}_{2}\left(\mathrm{CH}_{2}\right)_{12} \mathrm{CH}_{3}\right), 2.22$ (br m, $2 \mathrm{H}$, [C16-L-Ala], $\left.\mathrm{CH}_{2} \mathrm{CH}_{2}\left(\mathrm{CH}_{2}\right)_{12} \mathrm{CH}_{3}\right), 2.75$ (br s, 4H, [PCE], $\left.\left(\mathrm{C}_{5} \mathrm{H}_{4}\right)\left(\mathrm{CH}_{2}\right)_{2}\right)$, 5.65 (br s, 8H, [PCE], $\mathrm{Co}\left(\mathrm{C}_{5} \mathrm{H}_{4}\right)_{2}$ ).

Oxidation of monomeric cobaltocene derivatives: In a typical procedure, to a vial containing monomeric cobaltocene derivative (ca. 0.1 mml): bis(ethylcyclopentadienyl)cobalt(II) or the respective carba[n]cobaltocenophane $(n=2,3)$, was added an aqueous solution of respective chiral anionic surfactant $\mathrm{Na}$ [C 16 -L-Ala] or $\mathrm{Na}\left[\mathrm{C}_{16}\right.$-D-Ala] $\left(2 \mathrm{~mL}, 0.1 \mathrm{~mol} \mathrm{~L}^{-1}\right.$, ca. 2 eq. excess). To increase the solubility of the monomeric cobaltocene derivative and the resultant products, ethanol ( $5 \mathrm{~mL}$ ) and THF (5 mL) were also added to each vial. The mixtures were stirred vigorously in the presence of atmospheric oxygen for $24 \mathrm{~h}$, and the solutions were then directly subject to CD spectroscopy (see Fig. S6).

Synthesis of $\left[\mathrm{OCE}_{5}\right]\left[\mathrm{A}^{*}\right]_{5}$ : According to a reported procedure, ${ }^{43}$ to a solution of dicarba[2]cobaltocenophane (100 mg, $0.464 \mathrm{mmol}$ ) in THF (dried and distilled, $2.0 \mathrm{~mL}$ ) was added $12 \mathrm{mg}$ of $\mathrm{Li}\left({ }^{\mathrm{t} B u C} \mathrm{H}_{4}\right)(0.093 \mathrm{mmol}, 0.2 \mathrm{eq}$.). The deep red solution was stirred at room temperature and irradiated with Pyrex-filtered UV light for $16 \mathrm{~h}$, during which time a purple-brown suspension formed. The reaction was then quenched with degassed methanol (1.0 $\mathrm{mL})$.

To determine the degree of polymerization $\left(\mathrm{DP}_{\mathrm{n}}\right)$ of the neutral OCE, a $0.60 \mathrm{~mL}$ aliquot of the above suspension was added to a solution of ammonium triflate $\left(\mathrm{NH}_{4} \mathrm{OTf}\right.$ in 1:1 ethanol/water: $1 \mathrm{~mL}, 0.1 \mathrm{~mol} \mathrm{~L}^{-1}$, ca. 1 eq.) and ethanol $(5 \mathrm{~mL})$ was added. The mixture was stirred vigorously in the presence of atmospheric oxygen for $24 \mathrm{~h}$. After filtration, the solution was concentrated and dried under vacuum at room temperature. Integration of the corresponding peaks in the ${ }^{1} \mathrm{H}$ NMR spectrum (see Fig. S7) indicated that the resultant OCE had an average $\mathrm{DP}_{\mathrm{n}}$ of 5 .

To prepare the oligomeric chiral surfactant/PCE complexes, similarly a $0.60 \mathrm{~mL}$ aliquot of the $\mathrm{OCE}_{5}$ suspension was added to an aqueous solution of $\mathrm{Na}\left[\mathrm{C}_{16}-\mathrm{L}-\right.$ Ala], $\mathrm{Na}$ [C 16 -D-Ala], $\mathrm{Na}$ [C 16 -L-Phe] or $\mathrm{Na}$ [C $\mathrm{C}_{16}$-D-Phe] $(1 \mathrm{~mL}$ of $0.1 \mathrm{~mol} \mathrm{~L}^{-1}$, ca. 1 eq. $)$. Ethanol $(5 \mathrm{~mL})$ was then added to aid the dissolution of the resulting products and the mixture was stirred in the presence of atmospheric oxygen for $24 \mathrm{~h}$. After filtration, the solution was concentrated and then added drop-wise to $5 \mathrm{~mL}$ of rapidly stirred deionized 
water. The yellowish precipitate was isolated by centrifugation and dried under vacuum at room temperature. The products were redissolved in ethanol for further characterization by CD spectroscopy.

Self-assembly of [PCE $]\left[\mathbf{C}_{\mathbf{1 6}}-\mathrm{L}-\mathrm{Ala}\right]_{\mathbf{n}}$ : An ethanolic solution of [PCE][C $\left.\mathrm{C}_{16}-\mathrm{L}-\mathrm{Ala}\right]_{\mathrm{n}}\left(1 \mathrm{~mL}\right.$, ca. $\left.3 \mathrm{mg} \mathrm{mL}^{-1}\right)$ was transferred into a dialysis bag (MWCO $8000 \mathrm{~g} \mathrm{~mol}^{-1}$ ) and subjected to dialysis twice against THF (30 mL x 2), after which the material remained in solution, and twice against deionized water ( $30 \mathrm{~mL} \times 2$ ), after which a fine pale yellow precipitate was observed.

EDX analysis of aqueous [PCE][C16-L-Ala]n assemblies: Cobalt was detectable by spot EDX analysis on a carbon-coated copper TEM grid at positions A and B (Fig. 7d), corresponding to tightly-wound helices of high contrast to the grid (see Fig. S28). Spot C overlays an area of the TEM grid at the edge of another helical structure, although in this case the helix is more "relaxed" (the pitch length is greater than for those investigated by spots $A$ and B), which may be an inherent property of this particular helix, or a result of adhesion to the surface of the carboncoated grid upon drying (Fig. 7d). The presence of cobalt at this point could not be confirmed by EDX analysis (the net count was below the detection limit of the instrument), which may be a result of Spot $C$ not entirely overlaying the helix, and also the relaxed nature of the helix, where the concentration of cobalt is expected to be lower than that covered by spots A and B (also evident from the lower contrast relative to the grid). Cobalt was also undetectable in spot D, which represents an area of the grid not populated by any helices. Here, the precipitation of $[\mathrm{PCE}]\left[\mathrm{C}_{16}-\mathrm{L}-\mathrm{Ala}\right]_{\mathrm{n}}$ from aqueous solution upon selfassembly results in an absence of the film which was detected via drop casting of an ethanolic solution of the product.

\section{ASSOCIATED CONTENT}

Supporting Information. CD and NMR spectra, WAXS and DLS data, DSC and TGA scans, TEM, SEM and AFM images, and EDX analysis. This material is available free of charge on the ACS Publications website at DOI: $x x x x x x x x x x$.

\section{AUTHOR INFORMATION}

\section{Corresponding Authors}

1,*ian.manners@bristol.ac.uk

3,*hbqiu@sjtu.edu.cn

\section{Author Contributions}

All authors have given approval to the final version of the manuscript.

\section{Notes}

The authors declare no competing financial interest.

\section{ACKNOWLEDGMENT}

The authors wish to thank Dr. Sladjana Baljak for preliminary experiments, Prof. Charl Faul for helpful discussions, and Dr. Sean Davis and Jonathan Jones in the Chemistry Imaging Facility at the University of Bristol (UoB) with equipment funded by UoB and EPSRC (EP/K035746/1 and EP/M028216/1). R.A.M. and I.M. thank the EPSRC for funding (EP/N030702/1). H.Q. thanks the National Natural Science Foundation of China (21674062, U1632117, 21704063), the Science and Technology Commission of Shanghai Municipality (16ZR1422600, 16PJ1406600, 17JC1400700), Shanghai Education Development Foundation and Shanghai Municipal Education Commission (16SG54) for financial support.

\section{REFERENCES}

1. Hardy, C. G.; Zhang, J. Y.; Yan, Y.; Ren, L. X.; Tang, C. B., Prog. Polym. Sci. 2014, 39, 1742-1796.

2. Zhou, J. W.; Whittell, G. R.; Manners, I., Macromolecules 2014, 47, 3529-3543.

3. Winter, A.; Schubert, U. S., Chem. Soc. Rev. 2016, 45, 5311-5357.

4. Xiang, J.; Ho, C. L.; Wong, W. Y., Polym. Chem. 2015, 6, 6905-6930.

5. Zhang, K. Y.; Liu, S. J.; Zhao, Q.; Huang, W., Coord. Chem. Rev. 2016, 319, 180-195.

6. Wang, X. S.; McHale, R., Macromol. Rapid Commun. 2010, 31, 331-350.

7. Whittell, G. R.; Hager, M. D.; Schubert, U. S.; Manners, I., Nat. Mater. 2011, 10, 176-188.

8. Stanley, J. M.; Holliday, B. J., Coord. Chem. Rev. 2012, 256, 1520-1530.

9. Caruana, D. J.; Heller, A., J. Am. Chem. Soc. 1999, 121, 769-774.

10. Gajovic, N.; Binyamin, G.; Warsinke, A.; Scheller, F. W.; Heller, A., Anal. Chem. 2000, 72, 2963-2968.

11. Sui, X. F.; Feng, X. L.; Song, J.; Hempenius, M. A.; Vancso, G. J., J. Mater. Chem. 2012, 22, 11261-11267.

12. Valério, C.; Fillaut, J. L.; Ruiz, J.; Guittard, J.; Blais, J. C.; Astruc, D., J. Am. Chem. Soc. 1997, 119, 2588-2589.

13. Daniel, M. C.; Ruiz, J.; Astruc, D., J. Am. Chem. Soc. 2003, 125, 1150-1151.

14. Djeda, R.; Rapakousiou, A.; Liang, L. Y.; Guidolin, N.; Ruiz, J.; Astruc, D., Angew. Chem. Int. Ed. 2010, 49, 8152-8156.

15. Péter, M.; Lammertink, R. G. H.; Hempenius, M. A.; Vancso, G. J., Langmuir 2005, 21, 5115-5123.

16. Kulbaba, K.; Cheng, A.; Bartole, A.; Greenberg, S.; Resendes, R.; Coombs, N.; Safa-Sefat, A.; Greedan, J. E.; Stöver, H. D. H.; Ozin, G. A.; Manners, I., J. Am. Chem. Soc. 2002, 124, 12522-12534.

17. Puzzo, D. P.; Arsenault, A. C.; Manners, I.; Ozin, G. A., Angew. Chem. Int. Ed. 2009, 48, 943-947.

18. Eloi, J. C.; Ward Jones, S. E.; Poór, V.; Okuda, M.; Gwyther, J.; Schwarzacher, W., Adv. Funct. Mater. 2012, 22, 3273-3278.

19. Staff, R. H.; Gallei, M.; Mazurowski, M.; Rehahn, M.; Berger, R.; Landfester, K.; Crespy, D., ACS Nano 2012, 6, 90429049.

20. Ma, Y.; Dong, W.-F.; Hempenius, M. A.; Möhwald, H.; Vancso, G. J., Nat. Mater. 2006, 5, 724-729.

21. Thomi, L.; Schaefer, P.; Landfester, K.; Wurm, F. R., Macromolecules 2016, 49, 105-109.

22. MacLachlan, M. J.; Ginzburg, M.; Coombs, N.; Raju, N. P.; Greedan, J. E.; Ozin, G. A.; Manners, I., J. Am. Chem. Soc. 2000, 122, 3878-3891.

23. Ginzburg, M.; MacLachlan, M. J.; Yang, S. M.; Coombs, N.; Coyle, T. W.; Raju, N. P.; Greedan, J. E.; Herber, R. H.; Ozin, G. A.; Manners, I., J. Am. Chem. Soc. 2002, 124, 2625-2639. 
24. Hinderling, C.; Keles, Y.; Stöckli, T.; Knapp, H. F.; de los Arcos, T.; Oelhafen, P.; Korczagin, I.; Hempenius, M. A.; Vancso, G. J.; Pugin, R.; Heinzelmann, H., Adv. Mater. 2004, 16, 876-879.

25. Lastella, S.; Jung, Y. J.; Yang, H. C.; Vajtai, R.; Ajayan, P. M.; Ryu, C. Y.; Rider, D. A.; Manners, I., J. Mater. Chem. 2004, 14, 1791-1794.

26. Dong, Q.; Li, G. J.; Ho, C. L.; Faisal, M.; Leung, C. W.; Pong, P. W. T.; Liu, K.; Tang, B. Z.; Manners, I.; Wong, W. Y., Adv. Mater. 2012, 24, 1034-1040.

$27 . \quad$ Zhang, J. Y.; Yan, Y.; Chance, M. W.; Chen, J. H.; Hayat, J.; Ma, S. G.; Tang, C. B., Angew. Chem. Int. Ed. 2013, 52, 1338713391.

28. Guterman, R.; Kenaree, A. R.; Gilroy, J. B.; Gillies, E. R.; Ragogna, P. J., Chem. Mater. 2015, 27, 1412-1419.

29. Kenaree, A. R.; Berven, B. M.; Ragogna, P. J.; Gilroy, J. B., Chem. Commun. 2014, 50, 10714-10717.

30. Yashima, E.; Maeda, K.; Furusho, Y., Acc. Chem. Res. 2008, 41, 1166-1180.

31. Yashima, E.; Maeda, K.; Iida, H.; Furusho, Y.; Nagai, K., Chem. Rev. 2009, 109, 6102-6211.

32. Saleh, N.; Shen, C. S.; Crassous, J., Chem. Sci. 2014, 5, 3680-3694.

33. Katz, T. J.; Sudhakar, A.; Teasley, M. F.; Gilbert, A. M.; Geiger, W. E.; Robben, M. P.; Wuensch, M.; Ward, M. D., J. Am. Chem. Soc. 1993, 115, 3182-3198.

34. Dai, Y. J.; Katz, T. J., J. Org. Chem. 1997, 62, 12741285 .

35. Dai, Y. J.; Katz, T. J.; Nichols, D. A., Angew. Chem. Int. Ed. 1996, 35, 2109-2111.

36. Bernhard, S.; Goldsmith, J. I.; Takada, K.; Abruña, H. D., Inorg. Chem. 2003, 42, 4389-4393.

37. Bernhard, S.; Takada, K.; Díaz, D. J.; Abruña, H. D.; Mürner, H., J. Am. Chem. Soc. 2001, 123, 10265-10271.

38. Henze, O.; Feast, W. J.; Gardebien, F.; Jonkheijm, P.; Lazzaroni, R.; Leclère, P.; Meijer, E. W.; Schenning, A. P. H. J., J. Am. Chem. Soc. 2006, 128, 5923-5929.

39. Smulders, M. M. J.; Schenning, A. P. H. J.; Meijer, E. W., J. Am. Chem. Soc. 2008, 130, 606-611.

40. Yang, Y.; Zhang, Y. J.; Wei, Z. X., Adv. Mater. 2013, 25, 6039-6049.

41. Yashima, E.; Ousaka, N.; Taura, D.; Shimomura, K.; Ikai, T.; Maeda, K., Chem. Rev. 2016, 116, 13752-13990.

42. Nakagawa, M.; Kawai, T., J. Am. Chem. Soc. 2018, 140, 4991-4994.

43. Mayer, U. F. J.; Gilroy, J. B.; O’Hare, D.; Manners, I., J. Am. Chem. Soc. 2009, 131, 10382-10383.

44. Mayer, U. F. J.; Charmant, J. P. H.; Rae, J.; Manners, I., Organometallics 2008, 27, 1524-1533.

45. Hailes, R. L. N.; Oliver, A. M.; Gwyther, J.; Whittell, G. R.; Manners, I., Chem. Soc. Rev. 2016, 45, 5358-5407.

46. Gilroy, J. B.; Patra, S. K.; Mitchels, J. M.; Winnik, M. A.; Manners, I., Angew. Chem. Int. Ed. 2011, 50, 5851-5855.

47. Qiu, H.; Gilroy, J. B.; Manners, I., Chem. Commun. 2013, 49, 42-44.

48. Faul, C. F. J., Acc. Chem. Res. 2014, 47, 3428-3438.

49. Echue, G.; Hamley, I.; Jones, G. C. L.; Faul, C. F. J., Langmuir 2016, 32, 9023-9032.

50. Dane, T. G.; Cresswell, P. T.; Bikondoa, O.; Newby, G. E.; Arnold, T.; Faul, C. F. J.; Briscoe, W. H., Soft Matter 2012, 8, 2824-2832.

51. Antonietti, M.; Conrad, J., Angew. Chem. Int. Ed. 1994, 33, 1869-1870.

52. Thünemann, A. F., Polym. Int. 2000, 49, 636-644.
53. Takehara, M.; Yoshimura, I.; Takizawa, K.; Yoshida, R., J. Am. Oil Chem. Soc. 1972, 49, 157-161.

54. Sakamoto, K.; Yoshida, R.; Hatano, M.; Tachibana, T., J. Am. Chem. Soc. 1978, 100, 6898-6902.

55. Baczko, K.; Larpent, C.; Lesot, P., Tetrahedron: Asymmetry 2004, 15, 971-982.

$56 . \quad$ Che, S.; Liu, Z.; Ohsuna, T.; Sakamoto, K.; Terasaki, O.; Tatsumi, T., Nature 2004, 429, 281-284.

57. Che, S.; Garcia-Bennett, A. E.; Yokoi, T.; Sakamoto, K.; Kunieda, H.; Terasaki, O.; Tatsumi, T., Nat. Mater. 2003, 2, 801-805.

58. Zhang, J. Y.; Pellechia, P. J.; Hayat, J.; Hardy, C. G.; Tang, C. B., Macromolecules 2013, 46, 1618-1624.

59. Zhang, J.; Chen, Y. P.; Miller, K. P.; Ganewatta, M. S.; Bam, M.; Yan, Y.; Nagarkatti, M.; Decho, A. W.; Tang, C. B., J. Am. Chem. Soc. 2014, 136, 4873-4876.

60. Zhang, M. F.; Müller, A. H. E., J. Polym. Sci. A Polym. Chem. 2005, 43, 3461-3481.

61. Azzaroni, O., J. Polym. Sci. A Polym. Chem. 2012, 50, 3225-3258.

62. Attridge, C. J.; Baker, S. J.; Parkins, A. W., Organomet. Chem. Synth. 1971, 1, 183-184.

63. Saidel, L. J.; Lieberman, H., Arch. Biochem. Biophys. 1958, 76, 401-409.

64. Ren, L. X.; Zhang, J. Y.; Hardy, C. G.; Doxie, D.; Fleming, B.; Tang, C. B., Macromolecules 2012, 45, 2267-2275.

65. Pfeiffer, P.; Quehl, K., Chem. Ber. 1931, 64, 26672671.

66. Kirshner, S.; Ahmad, N.; Magnell, K., Coord. Chem. Rev. 1968, 3, 201-206.

67. Crassous, J., Chem. Soc. Rev. 2009, 38, 830-845.

68. Jones, S. C.; Barlow, S.; O'Hare, D., Chem. Eur. J. 2005, 11, 4473-4481.

69. Danila, I.; Riobé, F.; Piron, F.; Puigmartí-Luis, J.; Wallis, J. D.; Linares, M.; Ågren, H.; Beljonne, D.; Amabilino, D. B.; Avarvari, N., J. Am. Chem. Soc. 2011, 133, 8344-8353.

70. Harada, N.; Nakanishi, K.; Berova, N., In Electronic CD Exciton Chirality Method: Principles and Applications, in Comprehensive Chiroptical Spectroscopy: Applications in Stereochemical Analysis of Synthetic Compounds, Natural Products, and Biomolecules, Volume 2, 4th ed.; John Wiley \& Sons: New Jersey, 2012.

71. Telfer, S. G.; McLean, T. M.; Waterland, M. R., Dalton Trans. 2011, 40, 3097-3108.

72. Ahmed, R.; Hsiao, M. S.; Matsuura, Y.; Houbenov, N.; Faul, C. F. J.; Manners, I., Soft Matter 2011, 7, 10462-10471.

73. Ahmed, R.; Patra, S. K.; Chabanne, L.; Faul, C. F. J.; Manners, I., Macromolecules 2011, 44, 9324-9334.

74. Ahmed, R.; Priimagi, A.; Faul, C. F. J.; Manners, I., $A d v$. Mater. 2012, 24, 926-931.

75. Ahmed, R.; Patra, S. K.; Hamley, I. W.; Manners, I.; Faul, C. F. J., J. Am. Chem. Soc. 2013, 135, 2455-2458.

76. DLS experiments performed on $[\mathrm{PCE}][\mathrm{Cl}]_{\mathrm{n}}$ in water indicated $\mathrm{R}_{\mathrm{h}}=$ ca. $18 \mathrm{~nm}$ (from the size distribution by volume), corresponding to a weight-average molecular weight of ca. $19,000 \mathrm{~g} \mathrm{~mol}^{-1}$ for sodium polystyrene sulfonate (Böhme, U.; Scheler, U., Macromol. Chem. Phys., 2007, 208, 2254-2257).

77. DLS experiments were performed on both aqueous and ethanolic solutions of $[\mathrm{PCE}][\mathrm{Cl}]_{\mathrm{n}}$. Due to poor solvation of the polyelectrolyte in ethanol, the raw correlation data was poor and could not be modelled effectively.

78. Dialysis of ethanolic solutions of [PCE][C $\left.{ }_{16}-\mathrm{L}-\mathrm{Ala}\right]_{\mathrm{n}}$ against deionized water also resulted in helical assemblies, 
although it was found that dialysis first from ethanol into THF and then into water produced more well-defined consistent helices.

79. Collins, S.; Hong, Y.; Taylor, N. J., Organometallics 1990, 9, 2695-2703.
80. Chabanne, L.; Pfirrmann, S.; Lunn, D. J.; Manners, I., Polym. Chem. 2013, 4, 2353-2360.

81. Pangborn, A. B.; Giardello, M. A.; Grubbs, R. H.; Rosen, R. K.; Timmers, F. J., Organometallics 1996, 15, 1518-1520.

82. Nilsson, M., J. Magn. Reson. 2009, 200, 296-302. 